\title{
Improved Knee Function after Intraarticular Administration of a New Drug Combination: a Case Series Report
}

Felician Stancioiu', Dana Vlasceanu-Catanas ${ }^{1}$

\begin{abstract}
Degradation of the articular cartilage in arthritis involves both the cellular, functional component (chondrocytes, etc.) and the structural component (extracellular matrix with collagen, etc.) via distinct molecules and cross-talking pathways; this makes it difficult to re-establish physiological status after the pathological processes have begun. Minimally invasive procedures - intraarticular injections, IAI - were shown to be superior to oral medication, however the efficacy of current intraarticular injections is limited, probably because of their narrowed focus on one of the two pathological processes: cellular inflammation (steroids) or extracellular matrix diminution (hyaluronic acid). Here we describe for the first time the intraarticular administration of a combination of medicinal products with pleiotropic actions, which simultaneously addresses these processes. Starting in November 2015, 5 patients with arthritis were treated with 64 IAls (50 knee, 14 ankle) and followed up for up to 2 years. Significant and sustained improvement in articular pain, stiffness and function was observed in these patients; this was quantified with the Western Ontario and McMaster Universities Osteoarthritis (WOMAC) - Likert scale version. Xrays showed no deterioration after 2 years in a patient with grade I osteoarthritis, and improvement of the knee cartilage in a patient with grade III osteoarthritis.
\end{abstract}

Keywords: knee, intraarticular, cartilage, arthritis

\section{Rezumat}

Degradarea cartilajului articular din diverse tipuri și stadii de artrită implică atât componenta celulară (condrocite) cât și matricea extracelulară a cartilajului, prin intermediul unor molecule distincte și a unor căi patologice care se suprapun și se influențează reciproc; din această cauză sunt greu de readus la normal după începerea proceselor patologice. Procedurile minim invazive (injecții intraarticulare sau infiltrații) sunt superioare terapiilor cu administrare sistemică; cu toate acestea eficacitatea infiltrațiilor administrate în mod curent este limitată, probabil din cauză că au un focus limitat la una din cele două patofiziologii: inflamația celulară (corticosteroizii) sau diminuarea matricei extracelulare (acidul hialuronic). În acest articol descriem pentru prima dată administrarea intraarticulară a unei combinații de substanțe cu acțiune pleiotropică și care adresează simultan aceste procese. Începând cu noiembrie 2015 au fost administrate 64 injecții intraarticulare (IAI, 50 genunchi, 14 glezne) cu diferite compoziții la 5 pacienți care au fost urmăriți maxim 2 ani după aceste proceduri. S-a observat o îmbunătățire semnificativă și susținută a durerii, rigidității și funcției articulare, cuantificată cu versiunea Likert a scalei WOMAC (Western Ontario and McMaster Universities). Radiografic s-a evidențiat lipsa deteriorării articulare la 2 ani după IAI la pacienta cu osteoartită grad I, respectiv o îmbunătățire a cartilajului genunchiului la un pacient cu osteoartrită grad III.

Cuvinte cheie: genunchi, intraarticular, cartilaj, artrită 


\section{INTRODUCTION}

Pathological modifications of the large joints (knee, hip, shoulder, ankle) due to trauma and/or inflammation are a common occurrence, which increases as the general population gets simultaneously older and more active $^{1}$. Progress in this therapeutic area has not kept up with the increased need for more efficient treatments, an overall consideration which includes efficacy in reducing discomfort, cost of treatments, presence of adverse reactions and the long term effects on the function and structure of the joints, which may prompt the need for repeated or different treatments.

Systemic drugs (NSAIDS, steroids, diacerein, acetaminophen, etc) have important analgesic and antiinflammatory effects in osteoarthritis (OA), but there are limitations in their efficacy and they have welldocumented gastrointestinal and cardiovascular side effects ${ }^{2}$. Good results were obtained in some patients with supplements containing chondroitine sulfate, glucosaminoglycans, collagen, Curcuma, Boswellia, Harpagophytum, Uncaria, etc.; homeopathic treatments, both systemic and injectable, are also available with variying degree of success ${ }^{3,4}$.

Intraarticular injections (IAIs, infiltrations) are a less invasive, less risky and less expensive treatment option. The drugs most commonly used for such infiltrations are steroids and hyaluronic acid, and both seem to have important limitations: steroids rapidly reduce joint pain, but do not improve significantly stiffness or physical function ${ }^{2}$ and have important short - (Tachon syndrome ${ }^{5}$ ) and long-term side effects (more cartilage and joint degradation when compared to saline ${ }^{6}$ ), while hyaluronic acid has much less side effects when properly injected (ultrasound guidance is recommended by some clinicians) but their long-term efficacy is questioned $^{7}$. Good results were reported more recently after IAIs with PRP (platelet rich plasma ${ }^{3}$, autologous stem cells ${ }^{8,9}$, autologous protein solution ${ }^{10}$, ozone ${ }^{11}$, and interleukin 1 receptor antagonists ${ }^{12}$, however their cost is much higher than drug IAIs, leaving them out-ofreach for many patients.

Infiltrations using biological ultrafiltrates (marine Aflutop or veal - Actovegin) were previously done with various degrees of success ${ }^{13,14}$ etc. We propose that their beneficial actions can be significantly enhanced by the addition of substances with known, important and complementary actions: ascorbic acid (vit C) and dimethylsulfoxide (DMSO). Vit C is essential for collagen synthesis and modulation of mitochondrial activity in the hypoxic conditions of cartilage via hypoxia-inducible factor $1 \alpha(\mathrm{HIF}-1 \alpha)$, as well as an essential an- tioxidant cofactor for the ferrous-dependent enzymes mono- and di-oxygenases ${ }^{15}$, while DMSO is excellent for permeabilising tissues and cells to various substances, while at the same time having protective effects on stem cells which may mature in functional chondrocytes ${ }^{16,17}$, and also significant antiinflammatory and antioxidant actions ${ }^{18-20}$.

Here we report the successful administration through IAI of a new combination of three pharmaceutical products already available for medical use: deproteinated veal serum (Actovegin, Act) or fish extract (Aflutop, $\mathrm{Afl}$ ), together with vitamin $\mathrm{C}$ (vit $\mathrm{C}$ ) and dimethylsulfoxide (DMSO).

\section{Patients, treatment and results}

Patient 1 (November 2015 - January 2018)

First patient was a 68 year old female with HT, chronic sinusitis, obese (BMI - 35.4, who had difficulties walking, bending the knees, climbing stairs, for which she was taking NSAIDS and advised to lower body weight (which she tried repeatedly but unsuccessfully). She was taking $400 \mathrm{mg}$ Ibuprofen daily for the previous 2 months, but still was unable to walk up the stairs and was severely restricted by pain during household chores, with left knee being especially painful and stiff. WOMAC score was 27 total, 6 for pain subscale, 3 stiffness, 18 physical function.

A radiography of the knee done in 2015, showed bilateral femoro-tibial arthrosis with incipient reduction of the articular interline, especially on the internal aspect of the knees; also incipient femoro-patellar arthrosis.

Clinical evaluation showed both knees with mild periarticular swelling; left knee being more painful to palpation and with moderate periarticular tension (fibrosis), especially of the peripatellar ligaments.

In November 20157 IAIs were administered in both knees (4 in left, 3 in right knee) all with Aflutop only. Xilin $1 \mathrm{mg}$ was administered prior to IAI, and afterwards a topical cream was applied, which contained plant extracts, plant fat and DMSO.

After the first IAI which was done in the left knee, the patient reported less pain and discomfort and decided to continue with infiltrations in both knees. After 3 series of bilateral infiltrations administered in an 18 day interval the patient felt better, much less pain and discomfort and was able to walk up two flight of stairs and needed no more ibuprofen.

After 6 months - May 2016 - 4 more IAIs were administered ( 2 in each knee with 3 days in between) also with Aflutop; at this visit there was much less contrac- 
tion, swelling and tenderness in the articular capsules of both knees.

WOMAC score was 6 total - 1 for pain subscale, 0 for stiffness, 5 for physical function.

In November 2016 were administered 6 more IAIs (3 in each knee), all with Act+DMSO +Vit C) and in May 2017 were performed the final 6 IAIs, 2 with $\mathrm{Aflu}+\mathrm{DMSO}+\mathrm{Vit} \mathrm{C}$, and 4 with Act+DMSO +Vit C.

A bilateral knee radiograph was done in May 2017 which showed minimal narrowing of the femoro-tibial articular space present in the median part of articulation. The patient stated she has no pain, stiffness or alteration of physical function (WOMAC 0).

Patient was seen again in October 2017, again stated that she had no discomfort and no IAIs were administered. As of January 2018 the patient was still pain-free, with no discomfort or limitation of physical function of the knees.

Notable for this patient with grade 1 osteoarthritis is the rapid improvement (after the first 2 injections) and sustained effect both in reducing knee discomfort as well as stopping further deterioration of knee in 2 years.

\section{Patient 2 (March 2016- February 2018)}

75 year old male with heart failure NYHA class II, atrial fibrillation, stage II hypertension, stroke history, hypercholesterolemia, and postraumatic osteoarthritis of the left knee stage II-III (fell while playing with grandkid). His medication included Pradaxa, Concor, Pramistar and Tertensif.

Magnetic resonance imaging (MRI) of the knee was done in July 2014, and showed:

- narrowed tibio-femural space;

- left and right knee meniscus with greatly reduced dimensions and heterogenous structure;

- subcortical erosions of the internal femural condilus;

- moderate intraarticular liquid; suprapatelar bursa fused at transverse ligament.

Conclusion- Stage III gonarthrosis with degenerative modifications of menisci and ligaments

WOMAC initial total score was 23 ; with subscales pain 8 , stiffness 2, physical function 13 .

Patient used topical treatment with plant extracts for 2 years, which brought some relief, and he was administered 3 IAIs in left knee in March 7, 28, April 5 2016. Xilin $1 \mathrm{ml}$ and afterwards Aflutop was administered with all 3 IAIs; patient stated that he had much less pain and discomfort in left knee, improved painfree range of movement.

WOMAC final total score was 7 , with subscales: pain 2, 0 stiffness, 5 physical function.
Approximately 3 months after last IAI the patient injured again his left knee while playing with grandkid; and afterwards IAIs were not repeated.

Patient 3 (August 2016 - February 2018)

67 yo female with history of arthritis since childhood (linked to a streptococcal infection), insulino-dependent diabetes, stage III hypertension, dyslipidemia, ischemic cardiac disease.

Both knees and ankles were severely swollen, with important fibrosis and large, deforming osteophytes (Fig 1A, B and C). WOMAC initial total score was 52: with 12 on pain subscale, 4 for stiffness and 36 for physical function.

IAIs were done without anesthesic due to concerns about cardiac function (presence of bradycardic episodes with frequent ventricular and supraventricular extrasystole) and was monitored with Holter during the IAIs. This patient had severe pain during injection in the right knee, radiating upwards on the thigh, and also had 3 episodes of emesis immediately after Actovegin administration. After the patient reported being sensitive to and not consuming veal meat, Actovegin, was replaced with Aflutop and emesis did not happen again. The pain felt during IAIs subsided in minutes following the application of a plant-based topical cream with plant extracts. An improvement in pain, stiffness and physical function was reported starting with the day after IAIs. There was no increase in the frequency of extrasystole on the Holter EKG recorded during and 30 minutes after the IAIs on both patient knees and ankles.

There were 7 series of 4 IAIs each (both knees and ankles) administered to this patient; with variable intervals between them, noted in the brackets:

I (27 days) II (7 days) III (67 days) IV (16 days) V (52 days) VI (87 days) VII.

The initial "on demand" strategy made it possible to estimate which administration schedule would give the best results, and it showed that at least 2 IAIs spaced at 1 week interval were needed for longer term relief of discomfort (at least 60 days relief).

Patient was evaluated again in February 2018 (9 months after last IAIs) because of complaints about right knee discomfort. Pain in the right knee was causing most of the reported discomfort ("blocking" of the knee after standing for more than a few minutes - ex. waiting for the bus). At this time WOMAC total score was 22: pain 4, stiffness 2 , and physical function $16 . \mathrm{Pa}-$ tient requested and received an IAI in right knee only (Act+DMSO+vit C; patient had moderate pain during and about 15 minutes after injection but no emesis) 
Improved Knee Function after Intraarticular Administration of a New Drug Combination

Table 1. Dates and types of IAIs administered in Patient 3

\begin{tabular}{|l|l|l|l|l|}
\hline Date of IAls & Left knee & Right knee & Left ankle & Right ankle \\
\hline 03.08 .2016 & Aflutop & Act+DMSO+ vit C (pain, emesis) & Aflutop & Act+DMSO+vit C \\
\hline 30.08 .2016 & Aflutop & Act+DMSO+ vit C (pain, emesis) & Aflutop & Act+DMSO+vit C \\
\hline 07.09 .2016 & Act+DMSO+vit C (emesis) & Aflutop & Act+DMSO+vit C & Aflutop \\
\hline 22.11 .2016 & Afl+DMSO+vit C & Afl+DMSO+vit C & Afl+DMSO+vit C & Afl+DMSO+vit C \\
\hline 09.12 .2016 & Afl+DMSO+ vit C & Afl+DMSO+vit C & Afl+DMSO+vit C & Afl+DMSO+vit C \\
\hline 09.02 .2017 & Afl+DMSO+vit C & Afl+DMSO+vit C & Afl+DMSO+vit C & Afl+DMSO+vit C \\
\hline 08.05 .2017 & Afl+DMSO+vit C & Afl+DMSO+vit C & Afl+DMSO+vit C & Afl+DMSO+vit C \\
\hline
\end{tabular}

and the improvement in right knee discomfort and physical function was prompt.

Pictures from Figure 1A, B, C were taken after 2 series of treatments (IAI on August 3 and 30, 2016), and those in Figure $2 \mathrm{~A}, \mathrm{~B}$ and $\mathrm{C}$ were taken after 3 treatments (IAIs on Sept 7,2016); no significant changes in the respective articulations were noted since. Importantly, this patient allowed a direct comparison of the Aflutop-based and Actovegin-based IAIs. In this patient, the combination Actovegin+DMSO+vit $\mathrm{C}$, resulted in a much greater diminution of edema than those containing Aflutop (right knee vs left knee and to a lesser degree right ankle vs left ankle).
Patient 4 (July-February 2018)

71 year old male in otherwise good health (BMI 25.6), presented with bilateral grade III knee osteoarthritis. This was the most severe case of osteoarthritis of the 5 presented here; Beginning with 2014 he had discomfort in both knees, and he received IAIs with hyaluronic acid, which was painful when administered and did not bring much relief (probably was not administered intraarticular). Afterwards he received IAI with ketoprofen, which relieved pain for about 10-12 months, but after that the pain was more severe than before, and the status of both knees deteriorated rapidly. Patient had severe pain at night which prevented

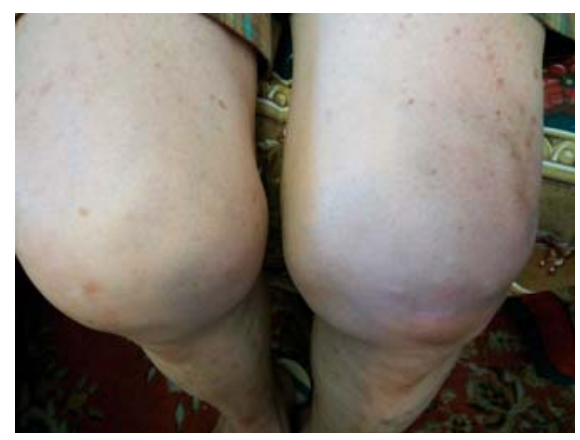

Figure 1A.

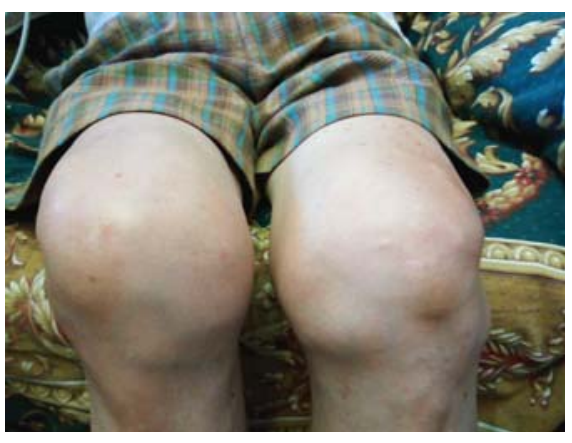

Figure 1B.

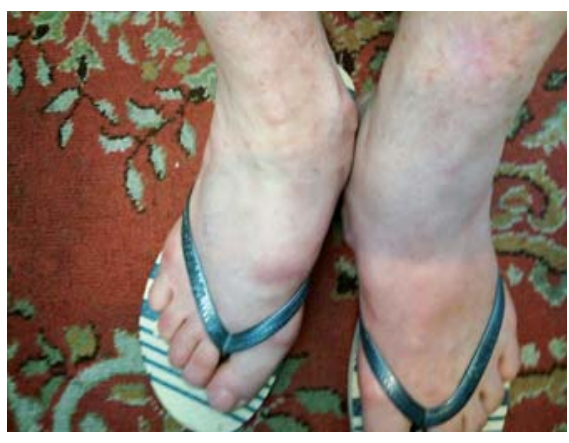

Figure 1C.

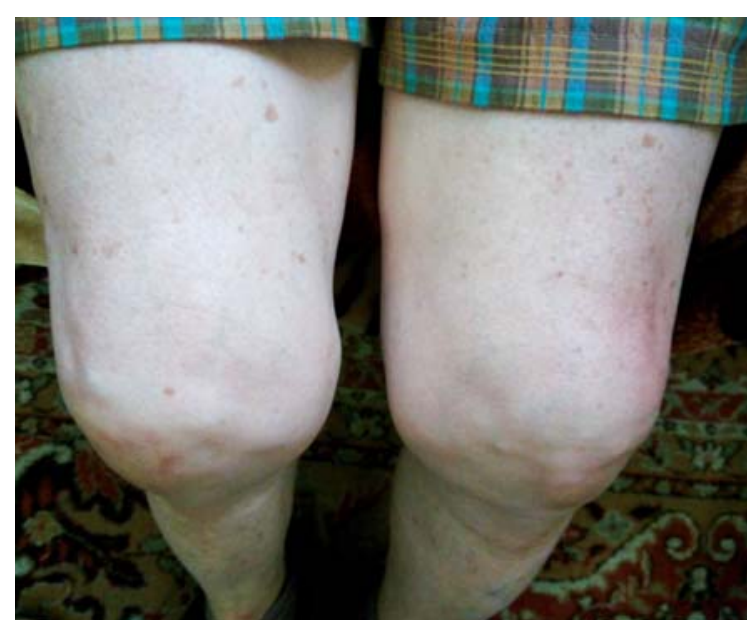

Figure 2A.

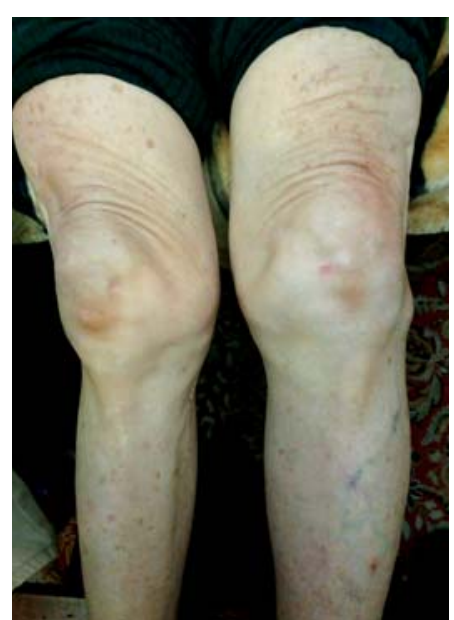

Figure 2B.

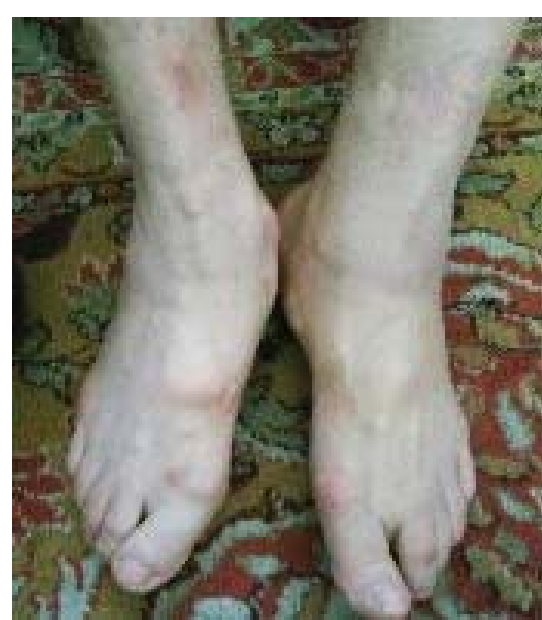

Figure 2C. 
him from sleeping and had extreme pain while bending knees, which made standing up very painful, and was able to walk only by keeping the knees straight (not bending the knees at all placed extra strain on hip joints).

Initial WOMAC total score was 62: pain 16, stiffness 7 , physical function 39 .

6 IAIs were administered in July, August and October 2017, 2 in each knee. First series was Afl alone, and the patient reported very little to no improvement, and was followed by two series of Act+DMSO+vit C. Patient reported improvement in pain (no more pain at night) after the first Act+DMSO+vit $\mathrm{C}$ injection, and had considerable less discomfort at walking after the second Actovegin-containing IAI (was able to bend the knee more easily).

Final WOMAC total score was 32, with subscales: pain 9, stiffness 5 , physical function 18 .

Figure $3 \mathrm{~A}$ and $3 \mathrm{~B}$ show $\mathrm{X}$-rays of the left knee in 2014 and 2016 respectively; there is a great reduction in the cartilage volume between the 2014 and $2016 \mathrm{ra}^{-}$ diograph. After 3 series of IAIs, an Xray of left knee done in February 2018 (shown in Figure 3C) showed an improvement in the area corresponding to the medial meniscus.

Patient 5 (September - December 2017)

49 year old female with history of gastritis, surgery for hiatal hernia repair, BMI 27.1, with episodic knee discomfort after minor but repeated traumatic events (including ski, specialized dancing, aikido, etc). Prior to IAIs the discomfort became continuous, impeding her in regular activities and difficult to relieve with medication. She had a MRI done 1 week prior to the IAI which showed bilateral tear of internal meniscus and bursitis.

WOMAC initial total score was 14: pain 4, stiffness 2, physical function 8 .

One IAI was administered in each knee, both IAIs with Act + DMSO + vit C. Patient had discomfort in the right knee immediately after the procedure; a cream with plant extracts applied topically helped relieve this discomfort. Next day patient reported no pain and improvement in stiffness and physical function; she needed no other treatments for knee discomfort and she restarted regular activities, including regular aikido training.

WOMAC final total score was 3: pain 1, stiffness 0 , physical function 2 , and stayed the same 3 months after the IAI.

In Figure 4 are charted the patients' initial and final WOMAC scores (before and after IAIs). Statistical significance was calculated with the $t$-test for all the WOMAC scores (total, as well as subscales: pain, stiffness, physical function). There was a statistically significant overall improvement when comparing the initial and final WOMAC scores in all 5 patients, for total WOMAC as well as subscale scores. For WOMAC total scores the two-tailed $t$-test value of $t$ is -4.692858 .

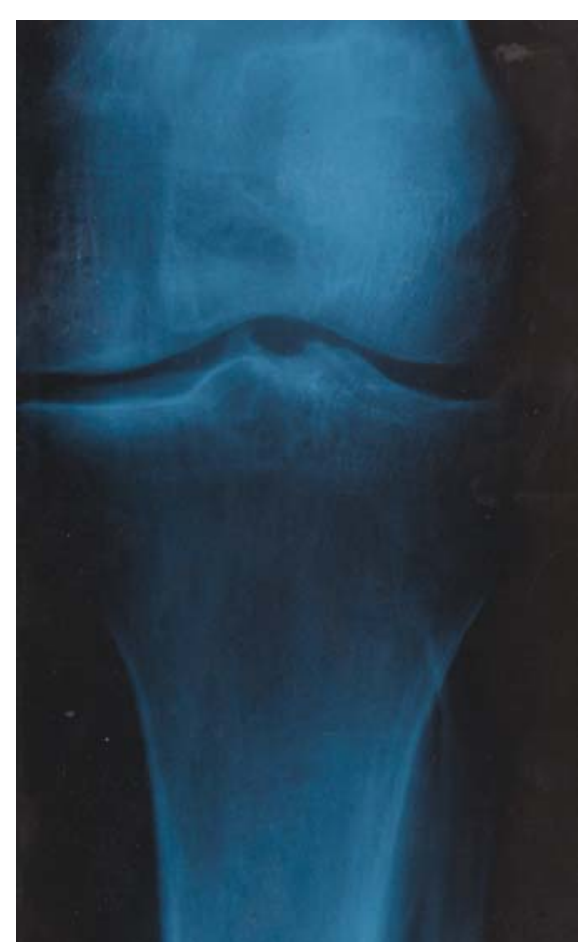

Figure 3A.

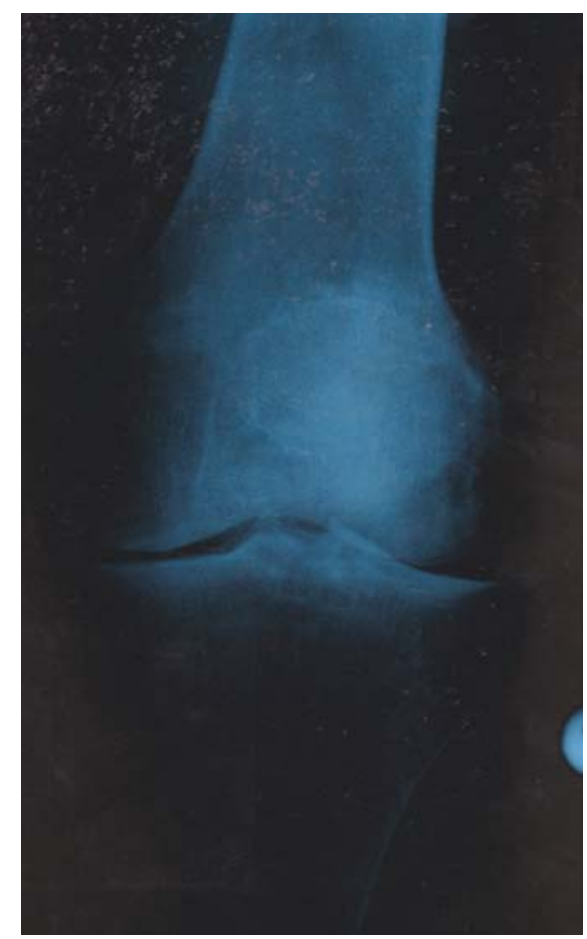

Figure 3B.

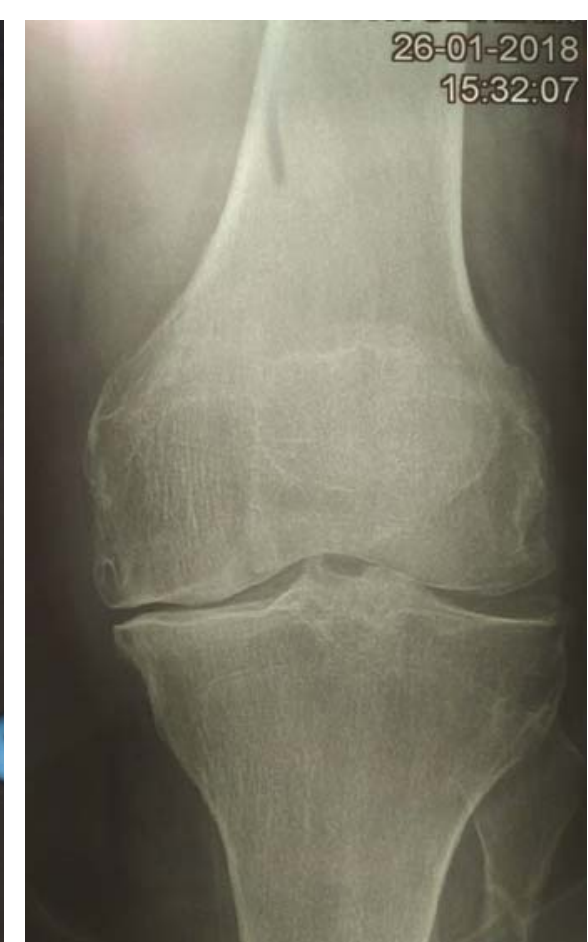

Figure 3C. 
and the value of $\mathrm{p}$ is 0.009 . For the pain subscale the value of $t$ is -7.839295 and the value of $\mathrm{p}$ is 0.001 . For the stiffness subscale, the value of $t$ is -9.797959 and the value of $\mathrm{p}$ is 0.0006 . For the physical function subscale, the value of $t$ is -3.436407 , and the value of $p$ is 0.026 .

After considering the results in the 5 patients treated with combination IAIs, the following observations are made:

- a minimum of 2 IAIs at 1 week interval are needed for initial long-term pain relief and discomfort; best results are given by a series of 3 IAIs spaced at 4-7 days interval;

- the effects of IAIs seem to be cumulative; the need for injections decreases over time;

- even though Aflutop had good results when administered by itself, the addition of DMSO and vitamin $\mathrm{C}$ increased its efficacy in reducing edema and pain;

- Aflutop and Actovegin had comparable results when used in combination with DMSO and $\mathrm{Vi}^{-}$ tamin C.

\section{DISCUSSION}

Even though the pathological processes in the OA joint are taking place simultaneously and are closely interlinked via direct or more complex molecular pathways, below we will focus on two main aspects:

I. cellular-level modifications, most importantly of chondrocyte function and structure, and

II. degradation of the extracellular matrix of the cartilage (collagen, GAGs, etc).
Furthermore we are detailing those aspects in four important processes, even though they overlap and simultaneously interact: inflammation; mitochondrial damage and apoptosis due to reactive oxygen species; collagen and extracellular matrix degradation; and availability of active substances at cellular level. The 4 processes mentioned are therapeutically addressed by the administration of the combination of substances via IAIs, and they are drawn together in Figure 5. As we are trying to present them as concise as possible, some of the molecules and paths linked to the ones represented are not mentioned in Figure 5.

\section{A. inflammation}

It was shown that the $\mathrm{OA}$ cartilage produces more TNF-alpha and TNF alpha convertase enzyme (TACE) than normal cartilage; and also that neutralizing TNF-alpha suppressed cartilage degradation in $\operatorname{arthritis}^{21}$.

OA cartilage also has an increase in IL-1beta and MMP-1 (matrix metalloprotease 1, collagenase) MMP-3 etc., and a LO (lipooxygenase) inhibitor had suppresive, beneficial actions ${ }^{22}$.

IL-1-induced phosphorylation of the mitogen-activated protein (MAP) kinases extracellular-signal regulated kinase (ERK), protein 38 (p38) and c-Jun Nterminal kinase (JNK), results in down-regulation of MMP gene expression in chondrocyte. Through various pathways, IL-1 stimulates prostaglandin E2, nitric oxide synthase, and matrix metalloproteases, inhibits collagen synthesis, augments activation of $\mathrm{T}$ and $\mathrm{B}$ lymphocytes and production of further pro-inflammatory cytokines, causes macrophages to release proteoly-
Figure 4. WOMAC scale scores with subscales for pain, stiffness and physical function, initially and after IAls for 5 patients.

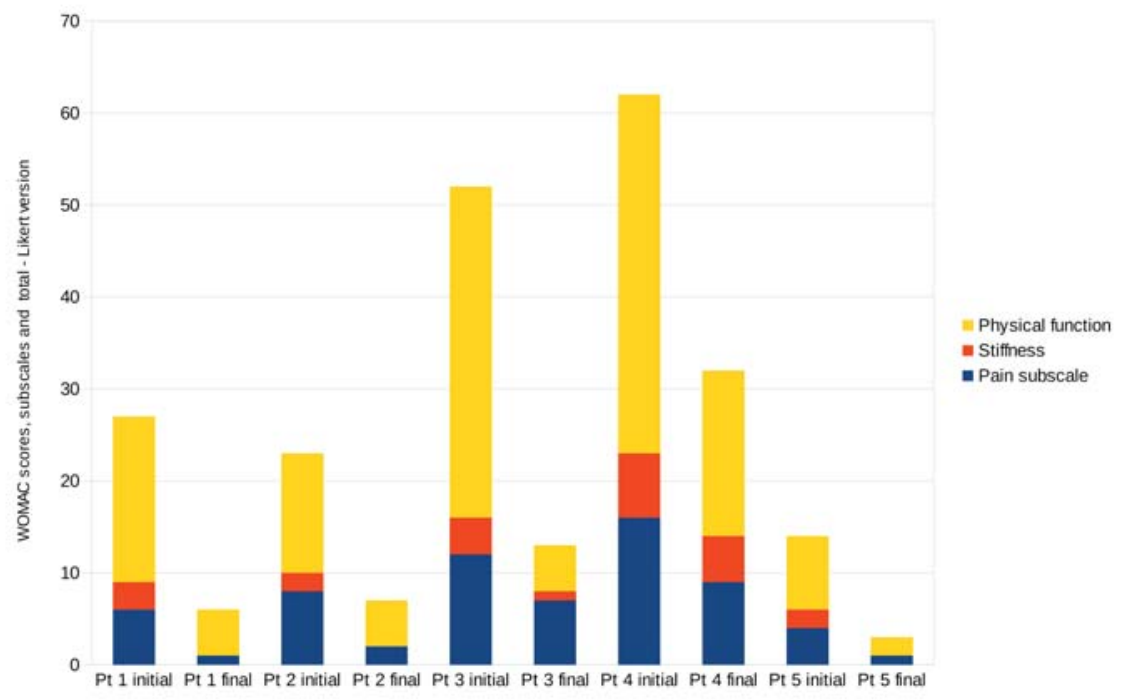




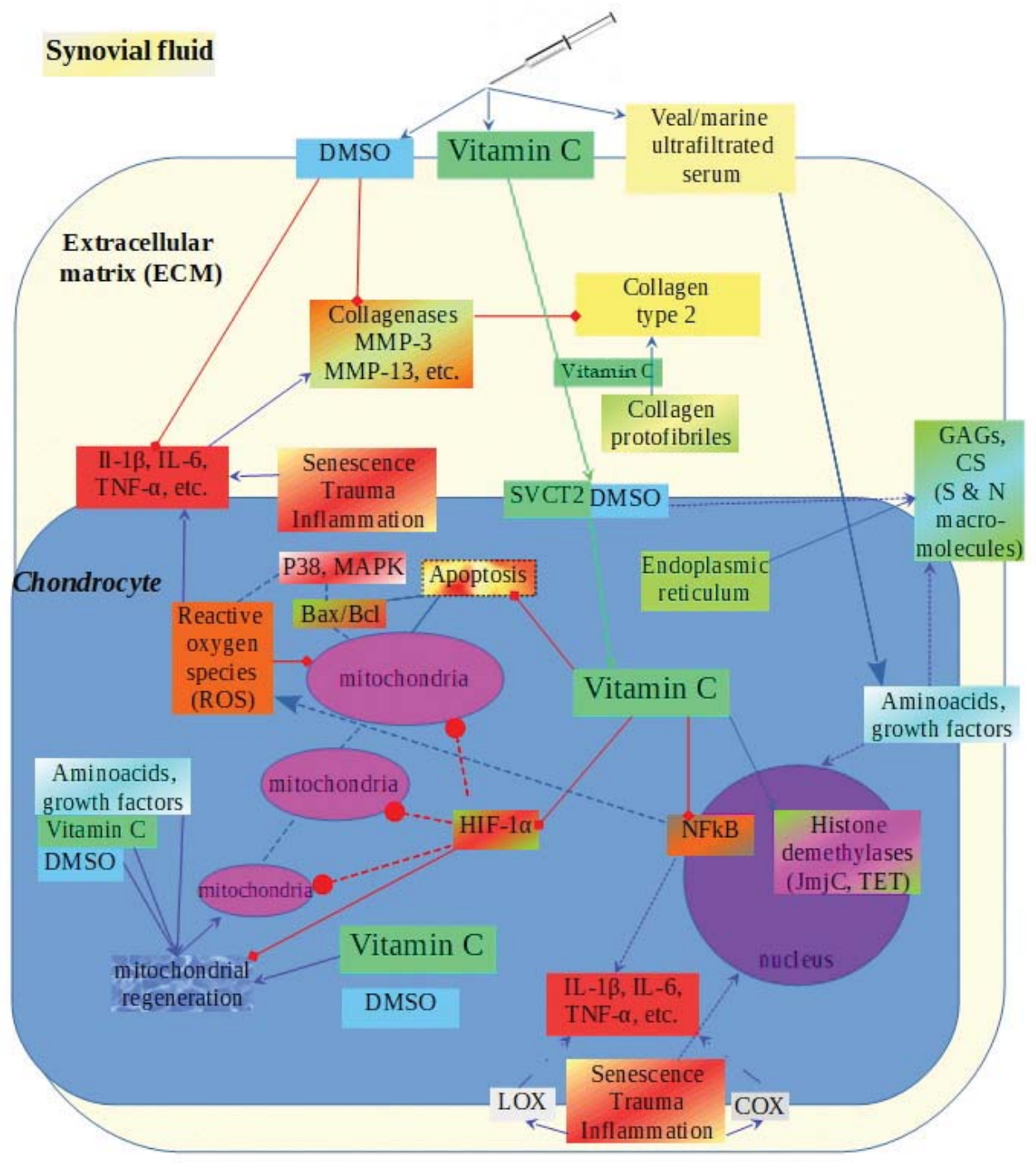

Figure 5. Cellular pathways involved in cartilage degeneration with intervening natural and therapeutic factors. NFkB - nuclear factor kappalight-chain-enhancer of activated B cells; MMP - matrix metalloprotease; IL-1 $\beta$, IL-6, TNF-a: interleukins -1 $\beta,-6$, tumor necrosis factor-a; HIF-1a - hipoxia-inducible factor; LOX, COX - lipo- and - cyclo-oxygenase; DMSO - dimethylsulfoxide; GAG, CS - glucosaminoglycans, chondroitine sulfate; SVCT2 - sodium-dependent vit C transporter type 2. PARP - Poly ADP-ribose polymerase, Vit C is essential cofactor in collagen synthesis, epigenetic regulator, and protector/promoter of mitochondrial function. Veal/marine serum is important source of aminoacids and growth factors. DMSO helps achieve useful drug concentration (vit C, peptides) in ECM and chondrocytes in the center of cartilage, compensates for impaired SVCT2 function, has direct antiinflammatory and antioxidant actions. (lines: continuous - direct action; dashed - indirect, mediated action; red - inhibitory, blue - stimulating, green - transport, black - interdependent, modulated, mediated relationship).

tic enzymes and chemotactic factors, and also stimulates osteoclasts to resorb bone, all of which promote joint degradation ${ }^{23}$.

As much as inflammation plays a major role in many cases of OA, in some forms of osteoarthritis it is neither the incipient nor the predominant factor, as is the case with the collagenase induced $\mathrm{OA}^{23}$, and this can be explained by the next two important types of processes which take place in the OA cartilage.

\section{B. Mitochondrial damage and apoptosis due to reac- tive oxygen and nitrogen species}

As is the case with all cells, mitochondria are of fundamental importance and they need to be protected from stressors, especially ROS, for preserving normal function of chondrocytes.

The following observations were made ${ }^{24}$ about mitochondria from OA chondrocyte

- they were more susceptible to damage induced by pro-inflammatory cytokines then mitochondria from normal chondrocytes; 
- cytokines increase reactive oxygen and nitrogen species within chondrocytes as well as mitochondrial superoxide production;

- increased NO production is the key factor responsible for accumulation of mtDNA damage after cytokine exposure;

- Pro-inflammatory cytokines IL-1 $\beta$ and TNF- $\alpha$ induce mitochondrial DNA damage, decrease energy production and mitochondrial transcription, and finally induce apoptosis;

- maintaining mitochondrial DNA integrity is necessary to prevent chondrocytes from apoptosis induced by IL-1 $\beta$ and TNF- $\alpha$.

Protection of human chondrocytes from mtDNA damage by the mitochondria-targeted DNA repair enzyme hOGG1 rescued mtDNA integrity, preserved ATP levels, reestablished mitochondrial transcription, and significantly diminished apoptosis following IL$1 \beta$ and TNF- $\alpha$ exposure.

A more direct correlation between oxidative damage and articular cartilage degeneration was shown in cartilage explants from QA patients, and that the presence of oxidative stress induces telomere genomic instability, replicative senescence and dysfunction of chondrocytes in the OA cartilage ${ }^{25}$. Furthermore, treatment of cultured chondrocytes with reactive oxygen species decreased telomere length, replicative capacity and GAG production.

The same author ${ }^{24}$ established that in articular cartilages from human $\mathrm{OA}$ patients, the expression of hypoxia-inducible factor-1 $\alpha$ (HIF-1 $\alpha)$ mRNA was higher in the degenerated regions than in the intact regions, and that HIF- $1 \alpha$ expression in the OA cartilage is associated with the progression of articular cartilage degeneration. Catabolic-stresses, IL-1beta, and oxidative stress induce the expression of HIF-1 $\alpha$ in chondrocytes, while inhibitors for phosphatidylinositol 3-kinase and p38 kinase cause a significant decrease in catabolic-factor-induced HIF-1 $\alpha$ expression.

HIF- $1 \alpha$ protein activates the transcription of genes that are of fundamental importance for oxygen homeostasis at the mitochondrial level, including genes involved in energy metabolism, angiogenesis, vasomotor control, apoptosis, proliferation, and matrix production, under hypoxic conditions.

HIF-1 $\alpha$ is also involved in the up-regulation of microsomal prostaglandin E synthase 1 (mPGES-1) and cyclooxygenase 2 (COX-2), while treatment with 2-methoxyestradiol lowers its activity ${ }^{27}$.

HIF-1 $\alpha$ protein is rapidly degraded by higher oxygen concentrations and most importantly its actions are inhibited by vit $\mathrm{C}^{28}$.

\section{Extracellular matrix degradation}

This is the most visible process on radiography and MRI and can have multiple causes: inflammation including infection and immune imbalance, mechanical trauma, oxidative stress, deficient DNA repair associated with stress and senescence, endocrine imbalance, deficit of vit $\mathrm{C}$, ferrous iron, nitrogen- or sulphur rich molecules and possibly other microelements.

Regeneration of the cartilage starts with the availability of the necessary components, both inside the chondrocytes where aminoacids (from Act/Afl) are assembled in the endoplasmic reticulum for collagen protofibrils, (also GAG, chondroitine sulfate, etc) under the epigenetic influence of growth factors and vit $\mathrm{C}$, as well as in the extracellular matrix, where vitamin $\mathrm{C}$ is essential cofactor for a variety of enzymes, including prolyl-3-hydroxylase ( $\mathrm{P} 3 \mathrm{H})$, prolyl-4-hydroxylase $(\mathrm{P} 4 \mathrm{H})$, and lysyl hydroxylase (LH), all which mediate collagen maturation and transformation of collagen protofibrills into full-strength collagen fibers.

Also important is the trans-membrane transport of these substances into chondrocytes. In the case of vit $\mathrm{C}$ it is estimated that suboptimal plasma concentrations (30 $\mu \mathrm{mol}$ or less) are present in a significant proportion of population, linked to improper nutrition or smoking or chronic conditions such as diabetes, which decrease its cellular availability. Complicating matters is the possibility of an impaired function of the sodium-dependent vitamin $\mathrm{C}$ transporter 2 (SVCT2), which ensures that vit $\mathrm{C}$ enters cells. Polymorphism in SVCT2 (Single Nuclear Polymorphysm in the SLC23A2 gene) is relatively frequent in the caucasian population and so far was linked to premature termination of pregnancy, neurodegeneration, head and neck squamous cell carcinoma, acute coronary syndrome in women ${ }^{29}$.

\section{Cellular availability of the medication through tissue permeation}

The dense, negatively charged matrix of cartilage is a major hurdle to the transport of potential therapeutics and the availability of medication to chondrocytes in the middle parts of the cartilage.

To this extent, the positively charged glycoprotein avidin was used as nanocarier for dexamethasone (Dex) and single intra-articular injections of Dex/low dose avidin-Dex were evaluated in rabbits, where it was observed that avidin-Dex suppressed injury-induced joint swelling and catabolic gene expression to a greater extent than free Dex $^{30}$.

It is worth noting that neither treatment (Dex alone or Dex-avidin) restored the loss of cartilage stiffness following cartilage tear, and the author suggested the 
need for a combinational therapy with a pro-anabolic factor for enhancing matrix biosynthesis ${ }^{30}$.

The therapeutic actions of the substances administered in our combination via IAI are numerous:

DMSO has excellent tissue penetration capabilities and ensures that the chondrocytes at the center of the cartilage receive useful concentrations of the medication injected in the joint. Besides being an excellent aprotic solvent and permeabilising membranes for other molecules (similar to nanocarriers), DMSO has direct and important cellular actions:

- inhibition of inflammation, specifically the NF$\kappa \mathrm{B}$ pathways, which lead to chondrocyte apoptosis. In OA, DMSO significantly suppresses the expression of many pro-inflammatory cytokines, chemokines and prostaglandin E2 (PGE2).via ERK1/2, p38, JNK and Akt phosphorylation ${ }^{20}$;

- the anti-inflammatory actions of DMSO also are seen in attenuation of NLRP3 inflammasome activation, IL-1 $\beta$ maturation, Caspase 1 activity, and ASC pyroptosome formation and mediates inhibition of IL-1s transcription ${ }^{19}$;

- in the human chondrocyte cell line C-28/I2, DMSO exhibits strong anti-inflammatory properties by blocking IL- 6 and IL-8 expression, both constitutive as well as IL- $1 \beta$-induced ${ }^{18}$.

Actovegin is a deproteinated ultrafiltrate of calf blood, composed of more than 200 biological substan$\operatorname{ces}^{31}$. Besides being an important source of peptides, minerals and growth factors, preclinical studies have shown that Actovegin increases glucose uptake and improves oxygen uptake in ischemic conditions; mitigates the effects of irradiation and stimulates wound healing; and also has anti-oxidative and anti-apoptotic mechanisms of action by inhibiting poly (ADP-ribose) polymerase (PARP) activity (which may trigger events leading to apoptosis).

Actovegin also stimulates production of the extracellular matrix components: hexosamine, uronic acid, hyaluronic acid, chondroitinsulfate and heparin, which contribute to regeneration of cartilage ${ }^{13}$.

Finally, Actovegin was shown to improve clinical outcomes and reduce return to sport time in professional players, most likely by modulating inflammation via CD68+ (which are elevated in OA synovial cells), and repair via $\mathrm{CD} 163+$ macrophages $^{32}$.

Afutop (Biotehnos, Romania) contains a marine fish bioactive concentrate (amino acids, low molecular mass peptides, mucopolysaccharides, trace elements: $\mathrm{Na}, \mathrm{K}$,
$\mathrm{Ca}, \mathrm{Mg}, \mathrm{Fe}, \mathrm{Cu}, \mathrm{Zn}$ ), and maximum $5 \mathrm{mg} / 100 \mathrm{ml}$ phenol as preservative. According to data from the summary of the medicinal product, it reduces inflammation, inhibits hyaluronidase excess; restores chondrocytes homeostasis in damaged tissues; stimulates regenerative processes of the cartilage; modulates synthesis of synovial fluid; stimulates superoxide dismutase; lowers formation of ROS. Intra-articular (IA) injections with Aflutop were shown to be effective in clinical trials. The recommended administration is 1-2 amps every third day into the joint for 21 days $^{33}$.

Vitamin $C$ plays essential roles in cartilage physiology, with major actions on both the cellular component (modulates functions of mitochondria and nuclei of chondrocytes, and consequently their function, maturation and apoptosis) and also on the extracellular matrix, where it acts as essential cofactor in collagen formation. Vit $\mathrm{C}$ protects chondrocyte mitochondria against oxidative damage and apoptosis, as well as nucleus by epigenetic modifications of nuclear DNA ${ }^{34}$.

In this regard, it is possible that the comparatively higher amounts of vit $\mathrm{C}$ present in the marine extract (Afl) makes it more effective for cartilage healing than the veal ultrafiltrate (Act).

The direct protective effect of $\mathrm{Vit} \mathrm{C}$ on chondrocytes was observed after OA cartilage explants were treated with reactive oxygen species or vit C (100.0 micromol/1). Treatment of cultured chondrocytes with reactive oxygen species shortened telomere length and replicative lifespan of chondrocytes, while treatment with vit $\mathrm{C}$ had opposite, beneficial effect on chondrocytes $^{23}$.

The important epigenetic actions of $\mathrm{Vit} \mathrm{C}$ on $\mathrm{nu}^{-}$ clear DNA is due to being an essential cofactor for reducing iron to $\mathrm{Fe}(\mathrm{II})$, a redox reaction which restores the catalytic activity of important enzymes: several histone- and DNA-modifying enzymes are Fe(II) 2oxoglutarate-dependent oxidases, as well as Jumonji $\mathrm{C}(\mathrm{JmjC})$-domain-containing histone demethylases which catalyze the removal of methyl groups from lysine residues of histone proteins in a two-step mechanism; the first step, an oxidative reaction requires $\mathrm{Fe}(\mathrm{II})$ and 2oxoglutarate ${ }^{15}$.

\section{CONCLUSIONS}

IAIs with marine or veal extract in combination with DMSO and vitamin $\mathrm{C}$ produced significant and sustained reductions in pain, stiffness and improved physical function in patients with osteoarthritis, and also in patients with cartilage tear. 
Addition of vit $\mathrm{C}$ and DMSO to Aflutop resulted in improved effects, so that IAIs could be reduced to 2 or 3 spaced at 1 week, from the recommended 7 done every 3 days, when only Aflutop is administered.

Finally, the addition of vit $\mathrm{C}$ and DMSO is also proposed for improving the therapeutic success of other substances or cell suspensions injected intraarticularly (platelet rich plasma, autologous plasma, cell prepara- tions, etc.), due to the essential roles played by ascorbic acid and DMSO described above, as well as in cell reprogramming (mesenchimal-to-somatic transition - Chen, 2013, and somatic into induced pluripotent stem cells - Wang, 2011 - all of which translate into therapeutic redress and makes possible the regeneration of the cartilage in the arthritic or traumatic joint.

\section{References}

1. Carnes J, Stannus O, Cicuttini F, Ding C, Jones G. Knee cartilage defects in a sample of older adults: natural history, clinical significance and factors influencing change over 2.9 years. Osteoarthritis Cartilage. 2012 Dec;20(12):1541-7. doi: 10.1016/j. joca.2012.08.026.

2. Bannuru RR, Schmid CH, Kent DM, et al. Comparative effectiveness of pharmacologic interventions for knee osteoarthritis: a systematic review and network meta-analysis. Ann Intern Med. 2015 Jan 6;162(1):46-54. doi: 10.7326/M14-1231.

3. Kon E, Filardo G, Drobnic M. et al. Non-surgical management of early knee osteoarthritis. Knee Surg Sports Traumatol Arthrosc. 2012. 20:436-449. DOI 10.1007/s00167-011-1713-8.

4. Lozada C, del Rio E, Reitberg D, et alTHU0441 Risk-Benefit of Co-Administered Traumeel ${ }^{\circledR}$ (TR14) and Zeel ${ }^{\circledR}$ (ZE14) Intra-Articular (IA) Injections in Patients with Moderate-to-Severe Pain Associated with OA of the Knee (OAK)Annals of the Rheumatic Diseases 2015;74:359.

5. Berthelot JM, Tortellier L, Guillot P, Prost A, Caumon JP, Glemarec J,et al. Tachon's syndrome (suracute back and/or thoracic pain following local injections of corticosteroids). A report of 318 French cases. Joint Bone Spine 2005;72(1):66-8

6. McAlindon TE, Lavalley MP, Harvey W et al. Effect of Intra-articular Triamcinolone vs Saline on Knee Cartilage Volume and Pain in Patients With Knee Osteoarthritis: A Randomized Clinical Trial. JAMA. 2017. 317. 1967. 10.1001/jama.2017.5283.

7. Goncars V, Kalnberzs K, Eriks Jakobsons E., et al. Treatment of Knee Osteoarthritis with Bone Marrow-Derived Mononuclear Cell Injection: 12-Month Follow-up. Cartilage 2018. 0. (0). 1-10 DOI: $10.1177 / 1947603517746721$

8. Jo $\mathrm{CH}$, Lee $\mathrm{YG}$, Shin $\mathrm{WH}$, et al. Intra-articular injection of mesenchymal stem cells for the treatment of osteoarthritis of the knee: a proof-of-concept clinical trial. Stem Cells. 2014; 32(5):1254-66. doi:10.1002/stem.1634.

9. Al najar M., et al. Intra-articular injection of expanded autologous bone marrow mesenchymal cells in moderate and severe knee osteoarthritis is safe: A phase I/II study. December 2017. Journal of Orthopaedic Surgery and Research 12(1). D0110.1186/s13018-017-0689-6

10. Hix, $\mathrm{J}$ et al. An Autologous Anti-Inflammatory Protein Solution Yielded a Favorable Safety Profile and Significant Pain Relief in an Open-Label Pilot Study of Patients with Osteoarthritis. BioResearch Open Access. Volume 6.1, 2017. DOI: 10.1089/biores.2017.0027.

11. Raeissadat S, Rayegani S M, Forogh, B et al. Intra-articular ozone or hyaluronic acid injection: Which one is superior in patients with knee osteoarthritis? A 6-month randomized clinical trial. Journal of Pain Research. 2018. Volume 11. 111-117. 10.2147/ JPR.S142755.

12. Barreto A, Braun T. A new treatment for knee osteoarthritis: Clinical evidence for the efficacy of Arthrokinex ${ }^{\mathrm{TM}}$ autologous

conditioned serum. Journal of Orthopaedics. 2017. Volume 14, Issue 1, March 2017, Pages 4-9.

13. Gulevsky, A.K. \& Grishchenko, V.I. \& Ivanov, E.G. Glycosaminoglycanes of cartilage tissue after the mechanical trauma: The influence of low-molecular fraction from the cord blood and blood of veal calves. Ukrain'skyi Biokhimichnyi Zhurnal. 2011. 83. 117-121.

14. Lee PYF, Brock J. Intra-articular Injections for Osteoarthritis: From Bench to Bedside, can we Teach Old Drugs New Tricks? JArthritis 5: e111. 2016. doi: 10.4172/2167-7921.1000e11.

15. Monfort A, Wutz A. Breathing-in epigenetic change with vitamin C. EMBO Rep. 2013 Apr;14(4):337-46. doi: 10.1038/embor.2013.29. Epub 2013 Mar 15.

16. Wang T, Chen $K$, Zeng $X$, Yang J, Wu Y, Shi X, Qin B, Zeng L, Esteban MA, Pan G, Pei D. The histone demethylases Jhdm1a/1b enhance somatic cell reprogramming in a vitamin-C-dependent manner. Cell Stem Cell. 2011 Dec 2;9(6):575-87. doi: 10.1016/j. stem.2011.10.005

17. Chen J, Guo L, Zhang L, Wu H, Yang J, Liu H, Wang X, Hu X, Gu T, Zhou Z, Liu J, Liu J, Wu H, Mao SQ, Mo K, Li Y, Lai K, Qi J, Yao H, Pan G, Xu GL, Pei D. Vitamin C modulates TET1 function during somatic cell reprogramming. Nat Genet. 2013 Dec;45(12):15049. doi: 10.1038/ng.2807. Epub 2013 Oct 27.

18. Kloesch B, Liszt M, Broell J, Steiner G. Dimethyl sulphoxide and dimethyl sulphone are potent inhibitors of IL- 6 and IL-8 expression in the human chondrocyte cell line C-28/I2. Life Sciences Volume 89, Issues 13-14, 26 September 2011, Pages 473-478

19. Ahn, H, Kim, J, Jeung, E-B, Lee G-S. Dimethyl sulfoxide inhibits NLRP3 inflammasome activation. Immunobiology, Volume 219, Issue 4, April 2014, Pages 315-322

20. Elisia I, Nakamura H, Lam V, et al. DMSO Represses Inflammatory Cytokine Production from Human Blood Cells and Reduces Autoimmune Arthritis. Proost P, ed. PLoS ONE. 2016; 11(3):e0152538. doi:10.1371/journal.pone.0152538.

21. Fernandes JC, Martel-Pelletier J, Pelletier JP. The role of cytokines in osteoarthritis pathophysiology. Biorheology. 2002;39(12):237-46.

22. He W, Pelletier JP, Martel-Pelletier J, Laufer S, Di Battista JA. Synthesis of interleukin 1 beta, tumor necrosis factor-alpha, and interstitial collagenase (MMP-1) is eicosanoid dependent in human osteoarthritis synovial membrane explants: interactions with antiinflammatory cytokines. J Rheumatol. 2002 Mar; 29(3):546-53.

23. Van Dalen SCM, Blom A, Slöetjes AW. Interleukin-1 is not involved in synovial inflammation and cartilage destruction in collagenase-induced osteoarthritis. Osteoarthritis and Cartilage. 2016. 25(3). DOl10.1016/j.joca.2016.09.009.

24. Kim J, Xu M, Xo R, Mates A, Wilson GL, Pearsall IV AW, Grishko $\checkmark$. Mitochondrial DNA damage is involved in apoptosis caused by pro-inflammatory cytokines in human OA chondrocytes. 
Felician Stancioiu et al.

Osteoarthritis and Cartilage. Volume 18, Issue 3, March 2010, Pages 424-432.

25. Yudoh $\mathrm{K}$, Nguyen vT, Nakamura $\mathrm{H}$, Hongo-Masuko $\mathrm{K}$, Kato $T$, Nishioka K. Potential involvement of oxidative stress in cartilage senescence and development of osteoarthritis: oxidative stress induces chondrocyte telomere instability and downregulation of chondrocyte function. Arthritis Res Ther. 2005;7(2):R380-91. Epub 2005 Jan 26.

26. Yudoh K, Nakamura H, Masuko-Hongo K, Kato T, Nishioka K. Catabolic stress induces expression of hypoxia-inducible factor (HIF)-1 alpha in articular chondrocytes: involvement of HIF-1 alpha in the pathogenesis of osteoarthritis. Arthritis Res Ther. 2005;7(4):R904-14. Epub 2005 May 27.

27. Grimmer C, Pfander D, Swoboda B, et al. Hypoxia-inducible factor 1alpha is involved in the prostaglandin metabolism of osteoarthritic cartilage through up-regulation of microsomal prostaglandin E synthase 1 in articular chondrocytes. Arthritis Rheum. 2007 Dec;56(12):4084-94.

28. Kuiper C, Dachs GU, Currie M, Vissers MC. Intracellular ascorbate enhances hypoxia-inducible factor (HIF)-hydroxylase activity and preferentially suppresses the HIF- 1 transcriptional response. Free Radic Biol Med. 2014 Apr;69:308-17. doi: 10.1016/j. freeradbiomed.2014.01.033.
29. Dalgård C, Christiansen L, Vogel U. et al. Variation in the sodium-dependent vitamin $\mathrm{C}$ transporter 2 gene is associated with risk of acute coronary syndrome among women. PloS one 2013, 8(8):e70421. DOI: 10.1371/journal.pone.0070421.

30. Bajpayee A., et al. Sustained intra-cartilage delivery of low dose dexamethasone using a cationic carrier for treatment of post traumatic osteoarthritis. European cells \& materials 34:341364. December 2017. DOI10.22203/eCM.v034a21.

31. Machicao F, Muresanu D, Hundsberger H. Pleiotropic neuroprotective and metabolic effects of Actovegin's mode of action. Journal of the neurological sciences. 2012. 322(1-2):222-7 D0l10.1016/j.jns.2012.07.069.

32. Lee PYF, Brock J. Intra-articular Injections for Osteoarthritis: From Bench to Bedside, can we Teach Old Drugs New Tricks? JArthritis 5: e111. 2016. doi: 10.4172/2167-7921.1000e11

33. Svetlova MS, Ignat'ev VK. Use of alflutop in the treatment of patients with osteoarthrosis. Klin Med (Mosk). 2004;82(6):52-5.

34. Camarena, V., \& Wang, G.The Epigenetic Role of Vitamin C in Health and Disease. Cellular and Molecular Life Sciences: CMLS, 2016. 73(8), 1645-1658. doi.org/10.1007/s00018-0162145-x. 